\title{
51. PETROLOGIC AND TECTONIC SIGNIFICANCE OF VOLCANIC CLASTS IN UPPER CRETACEOUS NANNOFOSSIL OOZE, DEEP SEA DRILLING PROJECT SITE 466, SOUTHERN HESS RISE ${ }^{1}$
}

\author{
T. L. Vallier, U. S. Geological Survey, 345 Middlefield Road, Menlo Park, California \\ K. E. Windom and K. E. Seifert, Department of Earth Sciences, Iowa State University, Ames, Iowa \\ and \\ F. Lee-Wong, U. S. Geological Survey, 345 Middlefield Road, Menlo Park, California
}

\begin{abstract}
Alkali-basalt clasts in Upper Cretaceous sediments from Site 466 on southern Hess Rise suggest that parts of Hess Rise were constructed by off-ridge volcanic activity. Apparently, tectonic adjustments at Hess Rise occurred during the Late Cretaceous (Campanian-Maastrichtian), when parts of the original volcanic pedestal were uplifted and provided source rocks for the clasts. Synchronous volcanism may have occurred. Causes for the Late Cretaceous tectonic adjustments (and volcanism?) are not known, but they may be related to intraplate movement along the Mendocino Fracture Zone.
\end{abstract}

\section{INTRODUCTION}

Site 466 on southern Hess Rise (Fig. 1) primarily was selected to recover a thick section of Tertiary carbonates for paleoenvironmental studies. We selected the site in a tectonic trough or graben, because the upper acoustically transparent layer is thicker than at any other possible site along seismic-reflection track lines in the area. The Tertiary section is not complete, however, and we drilled into a sequence of Upper Cretaceous chalk and chert beneath a lower Maastrichtian to middle Eocene lacuna.

Volcanic clasts recovered from the Upper Cretaceous sequence have both petrologic and tectonic significance. This paper describes the stratigraphic relationships, thin-section petrography, and pyroxene chemistry of the volcanic clasts and relates these data to the petrogenetic and tectonic histories of southern Hess Rise.

Standard thin sections of 23 clasts and polished thin sections of four clasts were cut. Of the 27 clasts, 18 are from volcanic flow rocks. The clasts are deeply weathered, and conventional whole-rock chemical analyses were not deemed worthwhile. Olivine is invariably altered, as is the groundmass. Pyroxene is least altered, and microprobe data are limited to that phase.

\section{STRATIGRAPHIC RELATIONSHIPS}

Clasts of volcanic rocks were recovered in Cores 10, $11,12,14,17,19,20,27,28$, and 29 (84-265 $\mathrm{m}$ subbottom depth). The clasts range from 1 to $7 \mathrm{~cm}$ in longest dimension. Most are rounded or subrounded. Colors are black and dark brown, and generally the clasts are partly covered with a white carbonate coating.

Poor recovery and deformation of the recovered sediments by coring hinder stratigraphic interpretation.

\footnotetext{
1 Initial Reports of the Deep Sea Drilling Project, Volume 62.
}

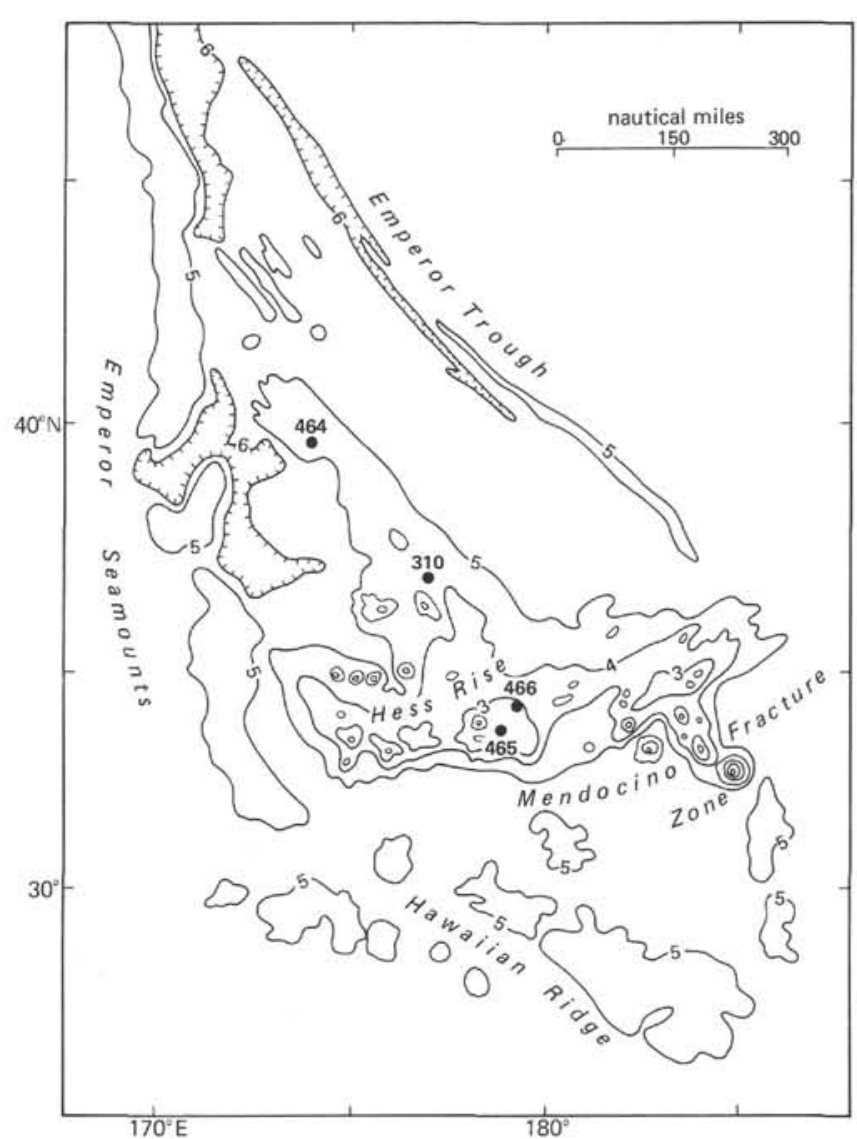

Figure 1. Map of southern Hess Rise (from Chase et al., 1970), showing bathymetry in kilometers and DSDP drill sites.

Total recovery was less than $20 \%$ in the sampled inter$\mathrm{val}$, and the sediments and rocks were either restricted to the core catcher or were very deformed and soupy materials in the core barrel proper. Original bedding was destroyed by the coring process. The abundance of 
chert and the presence of volcanic clasts contributed both to the poor recovery and to the core deformation.

We believe that the clasts were deposited during the late Campanian to early Maastrichtian, but possibly they were deposited along the pre-middle-Eocene unconformity and fell into the hole during the coring process, thus becoming incorporated in older strata.

The fossils of sediments in Core 10, the youngest core that contains volcanic clasts, are calcareous nannofossils of middle Eocene and Late Cretaceous (late Campanian to early Maastrichtian) ages and foraminifers of Paleocene (Core 10,CC) and Late Cretaceous (late Campanian to early Maastrichtian) ages. The age of Core 29 , the oldest core that contains a volcanic clast, is late Albian. The mixing of sediments of several ages in Core 10 may have been caused by sedimentary processes on the sea floor within the middle Eocene, or by coring and drilling.

A major hiatus of about 20 m.y. apparently separates the lower Maastrichtian and middle Eocene. This hiatus is not ubiquitous on southern Hess Rise. At Site 465, the section seems to be continuous from the upper Campanian through the upper Paleocene.

Most clasts were recovered from Cores 10 through 14. Strata in Cores 11 through 14 are of late Campanian to early Maastrichtian age. Farther down-hole, only two clasts were noted in Core 17, and one piece occurs in each of Cores 19, 20,27, 28, and 29. This suggests that the clasts were deposited in the younger Cretaceous sediments. The high linear sedimentation rates in the late Campanian to early Maastrichtian interval at Site $466(\sim 43 \mathrm{~m} / \mathrm{m} . \mathrm{y}$.$) and also at Site 465(\sim 42 \mathrm{~m} / \mathrm{m} . \mathrm{y}$.) indicate rapid sedimentation during that time, which may indicate some redeposition of sediments. Redeposited materials such as plant fibers, molluscan fragments, shelf benthic foraminifers, and glauconite occur in the upper Maastrichtian, upper Campanian, and Santonian at Site 465 , which indicates that some redeposition did occur during the Late Cretaceous along southern Hess Rise. Sand and gravel commonly fall into holes drilled by the Glomar Challenger and thereby contaminate older sediments. The alternative explanation-that the clasts had been deposited along the unconformity - must be considered in any petrologic or tectonic interpretations, but we conclude from the abundance of clasts in Cores 10 through 14, the high sedimentation rates, and the redeposited materials, that the clasts likely were deposited with the sediment of late Campanian to early Maastrichtian age.

\section{THIN-SECTION PETROGRAPHY}

The clasts have hyalopilitic and intersertal textures; two have flow-aligned feldspar laths, forming a pilotaxitic texture (Fig. 2A). Many are porphyritic, with phenocrysts of plagioclase, clinopyroxene, olivine, and opaque minerals, in an altered tachylite groundmass (Table 1; Figs. 2B and 2C). Intense alteration of some clasts by weathering has obscured primary phase relationships, which hinders identification and interpretation.

Plagioclase constitutes 1 to $46 \%$ by volume of the thin sections. Rarely, laths and microlites are rimmed by alkali feldspar, and some are replaced by a zeolite whose optical properties indicate that it is phillipsite. No unaltered olivine remains in any thin section. The olivine phenocrysts are replaced by iddingsite (5 samples), calcite ( 7 samples; Fig. 2B), and smectite (1 sample). The maximum olivine content was originally $11 \%$ in Sample 14,CC. Considering all pseudomorphs, clinopyroxene originally occurred in at least 8 thin sections (Table 1; Fig. 2C). Four thin sections have pseudomorphs of mafic minerals whose original compositions cannot be determined optically. Tachylite groundmasses are mostly replaced by clay minerals (brown smectite), and rarely by phillipsite and calcite.

Vesicles and amygdules constitute a total of 0 to $45 \%$ by volume (Table 1; Fig. 2D). Sizes range from 1 to 3 $\mathrm{mm}$ in longest dimension. Some vesicles are unlined, whereas others are lined by smectite. Amygdules are filled with calcite ( 9 samples), smectite (2 samples), and phillipsite (3 samples; Fig. 2D). Smectite minerals were first to form in the vesicles, followed by calcite or phillipsite.

The abundance of glassy groundmasses indicates rapid quenching of low-viscosity magmas. The mineralogy is characteristic of alkali basalt and alkali olivine basalt. Some of the more-crystalline clasts may be moresilicic differentiates, but the basaltic rocks definitely are dominant.

\section{CLINOPYROXENE CHEMISTRY}

Clinopyroxene phenocrysts and granules in Samples $12-1,92 \mathrm{~cm}$ and 19,CC were analyzed by microprobe. Oxide percentage, the number of cations based on 6 oxygens, and molecular percent are given in Table 2, and the molecular percentages are plotted on a triangular diagram in Figure 3. The molecular percent of wollastonite is plotted against $\mathrm{Al}_{2} \mathrm{O}_{3}$ and $\mathrm{Na}_{2} \mathrm{O}$ in Figures 4 and 5 , respectively.

A notable characteristic of the pyroxene oxide percentages is the relatively high $\mathrm{CaO}$ content. This is reflected in the triangular diagram (Fig. 3), where the data points cluster in the salite field. High $\mathrm{CaO}$ (high wollastonite molecular percentage) is characteristic of clinopyroxene from alkalic rocks. Plots of molecular percent wollastonite versus $\mathrm{Al}_{2} \mathrm{O}_{3}$ (Fig. 4) and $\mathrm{Na}_{2} \mathrm{O}$ (Fig. 5), following the procedure of Fodor et al. (1975, p. 187), show that the clinopyroxenes lie in the field of mafic alkalic basalt and nephelinite, toward the nephelinitic end. These plots establish satisfactorily the alkalic nature of the clasts.

\section{PETROLOGIC AND TECTONIC SIGNIFICANCE}

Clinopyroxene chemistry indicates the alkalic nature of the rocks, and thin-section petrography suggests that most clasts are alkali basalt. Some clasts may represent more-silicic differentiates of an alkali-basalt magma. We know that both tholeiitic basalt (Site 464 on northern Hess Rise) and trachyte (Site $\mathbf{4 6 5}$ on southern Hess Rise) make up parts of the volcanic platform (Seifert et al., this volume). We suspect that tholeiitic basalt forms the lower parts of Hess Rise, and that the alkalic suite forms the seamounts and drowned islands. Therefore, 

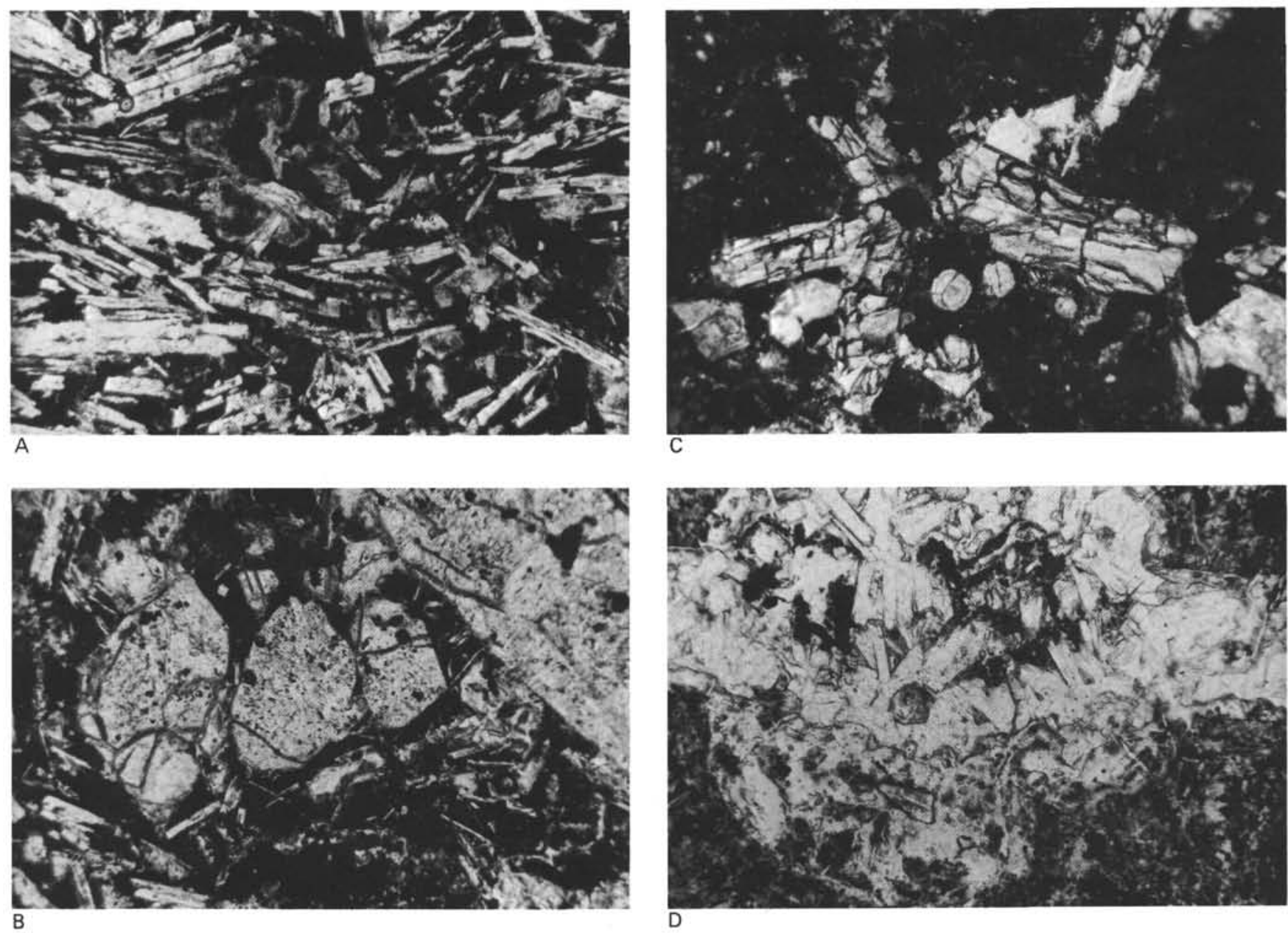

Figure 2. Photomicrographs (plane-light) of thin-sections from volcanic clasts from Site 466. All are 1.4-mm long. A. Flow-aligned feldspar laths in an altered tachylite groundmass [466-12,CC (F)]. B. Calcite pseudomorphs after olivine phenocrysts [466-12,CC (D)]. C. Clinopyroxene glomerol $[466-19, C C]$ that was microprobed. D. Phillipsite amygdule [466-12-1, $20 \mathrm{~cm}$ (D)].

Table 1. Petrography of volcanic clasts in Upper Cretaceous sediments, DSDP Site 466.

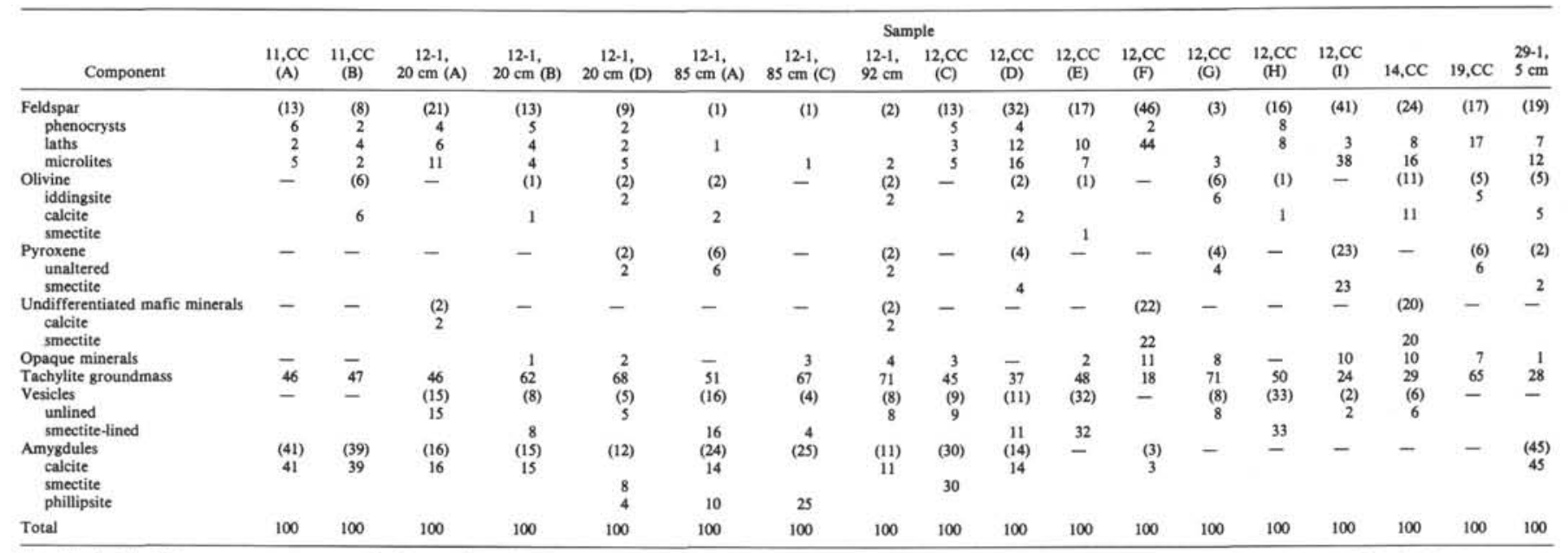

Note: Totals (vol. \%) for component groups are given in parentheses. Sample numbers show location in cores; last letter designates the clasts selected from one interval. Small clasts from $11, \mathrm{CC}$ had 100 points counted. Remainder had 400 to 500 points counted. Iddingsite, calcite, and smectite replace olivine; smectite replaces pyroxene; calcite, smectite, and zeolites fill vesicles to form amygdules. Pyroxene microprobe analyses were made on $12-1,92 \mathrm{~cm}$ and $19, \mathrm{CC}$. 
Table 2. Clinopyroxene chemistry, Hole 466, Samples 12-1, $92 \mathrm{~cm}$ and $19, \mathrm{CC}$.

\begin{tabular}{|c|c|c|c|c|c|}
\hline \multirow[b]{2}{*}{ Component } & \multicolumn{5}{|c|}{ Analyses } \\
\hline & 1 & 2 & 3 & 4 & 5 \\
\hline \multicolumn{6}{|c|}{ Oxides (wt. \%) } \\
\hline $\mathrm{SiO}_{2}$ & 50.57 & 51.09 & 48.17 & 49.97 & 48.16 \\
\hline $\mathrm{TiO}_{2}$ & 0.89 & 0.91 & 1.41 & 0.88 & 1.25 \\
\hline $\mathrm{Al}_{2} \mathrm{O}_{3}$ & 3.14 & 3.39 & 5.76 & 4.32 & 5.50 \\
\hline $\mathrm{Cr}_{2} \mathrm{O}_{3}$ & 0.22 & 0.29 & 0.22 & 0.23 & 0.36 \\
\hline $\mathrm{FeO}$ & 7.29 & 7.47 & 8.20 & 7.11 & 7.59 \\
\hline $\mathrm{MnO}$ & 0.13 & 0.13 & 0.11 & 0.11 & 0.13 \\
\hline $\mathrm{MgO}$ & 14.50 & 14.45 & 12.98 & 13.66 & 13.50 \\
\hline $\mathrm{CaO}$ & 22.67 & 21.73 & 22.07 & 22.40 & 22.16 \\
\hline $\mathrm{Na}_{2} \mathrm{O}$ & 0.45 & 0.53 & 0.74 & 0.61 & 0.64 \\
\hline Total & 99.86 & 99.99 & 99.66 & 99.29 & 99.29 \\
\hline \multicolumn{6}{|c|}{ Number of cations on the basis of 6 oxygens } \\
\hline $\mathrm{Si}$ & 1.886 & 1.897 & 1.811 & 1.872 & 1.814 \\
\hline $\mathrm{Al}_{\mathrm{VI}}^{\mathrm{IV}}$ & 0.114 & 0.103 & 0.189 & 0.128 & 0.186 \\
\hline $\mathrm{Al}$ VI & 0.025 & 0.045 & 0.066 & 0.063 & 0.058 \\
\hline $\mathrm{Ti}$ & 0.025 & 0.025 & 0.040 & 0.025 & 0.035 \\
\hline $\mathrm{Cr}_{2}$ & 0.007 & 0.008 & 0.007 & 0.007 & 0.011 \\
\hline $\mathrm{Fe}^{2+}$ & 0.227 & 0.232 & 0.258 & 0.223 & 0.239 \\
\hline $\mathrm{Mn}$ & 0.004 & 0.004 & 0.004 & 0.003 & 0.004 \\
\hline $\mathrm{Mg}$ & 0.806 & 0.800 & 0.728 & 0.763 & 0.758 \\
\hline $\mathrm{Ca}$ & 0.906 & 0.864 & 0.889 & 0.899 & 0.894 \\
\hline $\mathrm{Na}$ & 0.033 & 0.039 & 0.054 & 0.044 & 0.047 \\
\hline \multicolumn{6}{|c|}{ Molecular percent } \\
\hline Wo & 46.7 & 45.6 & 47.4 & 47.7 & 47.3 \\
\hline En & 41.6 & 42.2 & 38.8 & 40.5 & 40.1 \\
\hline Fs & 11.7 & 12.2 & 13.7 & 11.8 & 12.6 \\
\hline
\end{tabular}

1. 466-12-1, $92 \mathrm{~cm}$ : small phenocryst.

2. 466-19,CC: phenocryst core.

3. 466-19,CC: phenocryst edge.

4. 466-19,CC: lath.

5. 466-19,CC: small phenocryst.

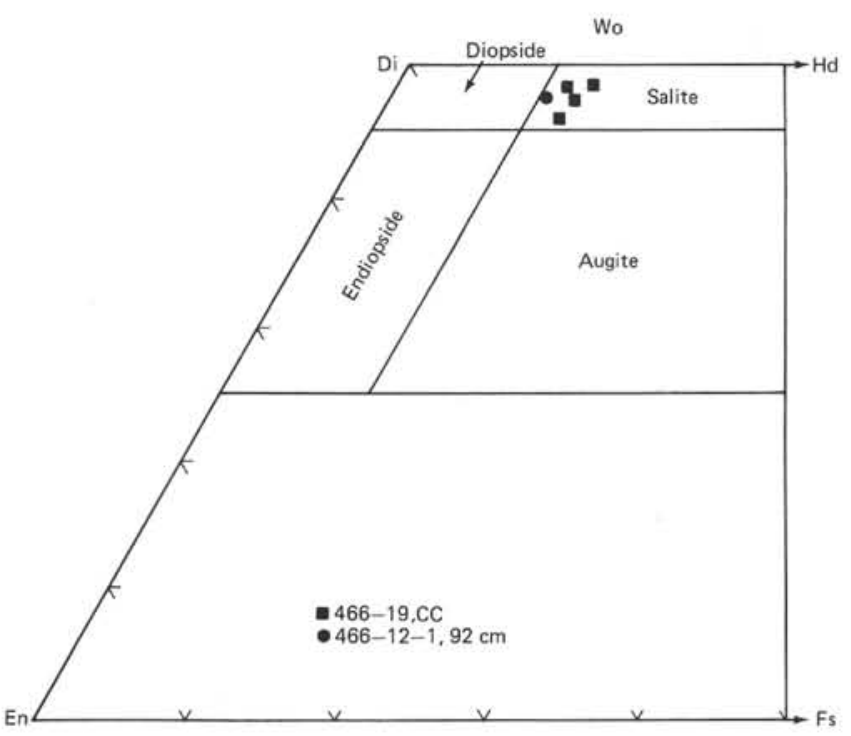

Figure 3. Part of a triangular diagram (Wo-En-Fs) showing molecular percentages for clinopyroxenes in Samples 466-19,CC and $466-12-1,92 \mathrm{~cm}$.

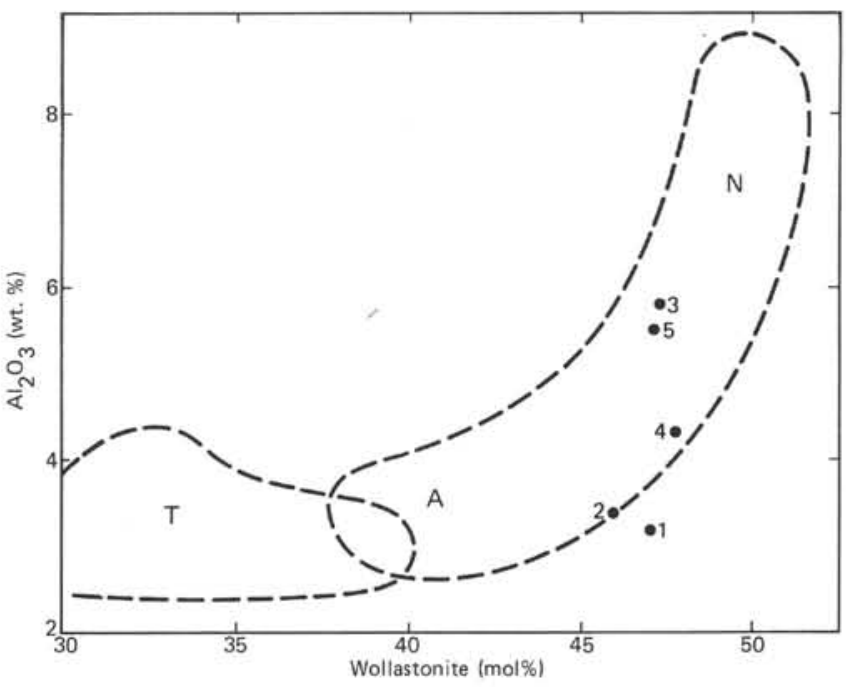

Figure 4. Diagram of weight percent $\mathrm{Al}_{2} \mathrm{O}_{3}$ versus molecular percent wollastonite. Fields are T, tholeiite; A, alkali basalts; and N, nephelinite. Dashed lines outline probable fields from data given by Fodor et al. (1975). Numbers correspond to pyroxene analyses in Table 2.

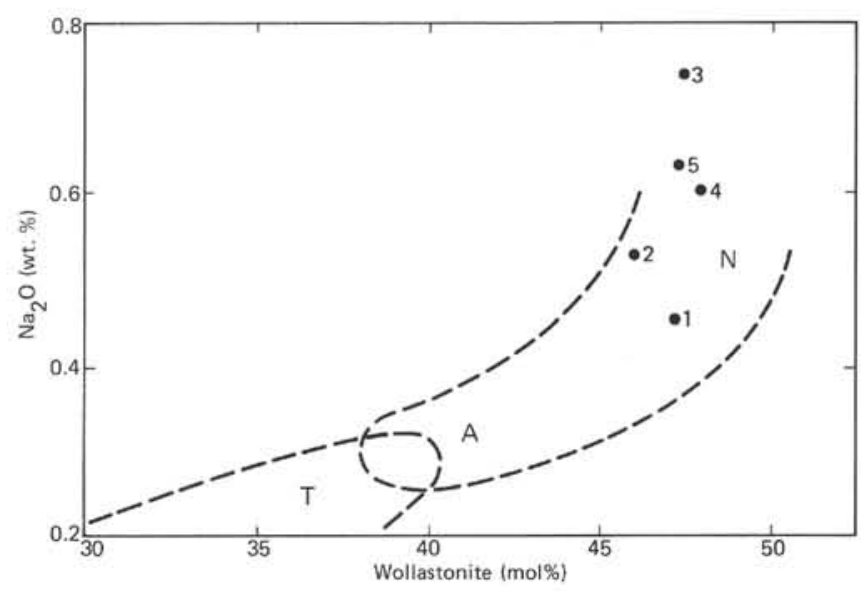

Figure 5. Diagram of weight percent $\mathrm{Na}_{2} \mathrm{O}$ versus molecular percent wollastonite. Fields and numbers are the same as in Figure 4.

the petrologic data suggest that Hess Rise was initiated at a mid-ocean ridge, where a tholeiitic base was formed, and that later off-ridge volcanism created the platform as a volcanic archipelago, which occurred before late Albian time according to the age of overlying sediments.

Judging from the stratigraphic data, we previously concluded that the clasts likely occur in strata of Late Cretaceous (late Campanian to early Maastrichtian) age, but we also suggested that the clasts possibly were incorporated into the Cretaceous core material from an original stratigraphic position along the early Maastrichtian to middle Eocene unconformity during the drilling and coring processes. Regardless of their vintage these alkali-basalt clasts record important volcanic and 
tectonic events along southern Hess Rise. Nearby volcanic outcrops were eroded, and the clasts were transported to Site 466 .

Site 466 is near a graben wall that bounds the north side of a ridge which forms the main part of southern Hess Rise (Fig. 6). Other extensional features on Hess Rise may be related to the same tectonic event that formed this graben. Parts of the ridge were likely above sea level during the late Campanian to early Maastrichtian (and probably later), and the clasts were eroded from islands along this rejuvenated volcanic platform. We have not determined the age of the clasts themselves, which means that they could be related either to the older volcanic pedestal or to younger volcanic islands that formed upon Hess Rise during the Late Cretaceous. Some data suggest a Late Cretaceous (Campanian to Maastrichtian) volcanic event (Vallier and Jefferson, this volume) that might be related to tectonic adjustment of Hess Rise or to passage of the feature over a mantle hot spot. Some of the prominent, and possibly younger, seamounts on southern Hess Rise (Fig. 1) may be related to that event.

We do not fully understand the cause of the event. It definitely occurred before formation of the Hawaii-
Emperor Bend, $42 \pm 1.4$ m.y. ago (Dalrymple and Clague, 1976), and is younger than adjacent parts of the Mendocino Fracture Zone, which offsets Early Cretaceous anomalies in the western Pacific. It may be related to renewed movement along the Mendocino Fracture Zone, but our data are not sufficient to test this possibility.

\section{SUMMARY}

Clasts of alkali basalt and possibly some silicic differentiates of alkali-basalt magma occur in Upper Cretaceous strata at Site 466 on southern Hess Rise. Their alkalic compositions are indicated by thin-section petrography and clinopyroxene chemistry. The origin of these clasts is unknown, but we believe that they were eroded from what is now the highest parts of southern Hess Rise. The clasts may have been eroded from an uplifted part of the old volcanic pedestal (upper Albian), or from islands that were created during Late Cretaceous volcanism. We do not understand the cause of this tectonic (and volcanic?) activity, but it may be related to renewed activity along the Mendocino Fracture Zone or to the passage of Hess Rise over a mantle hot spot.

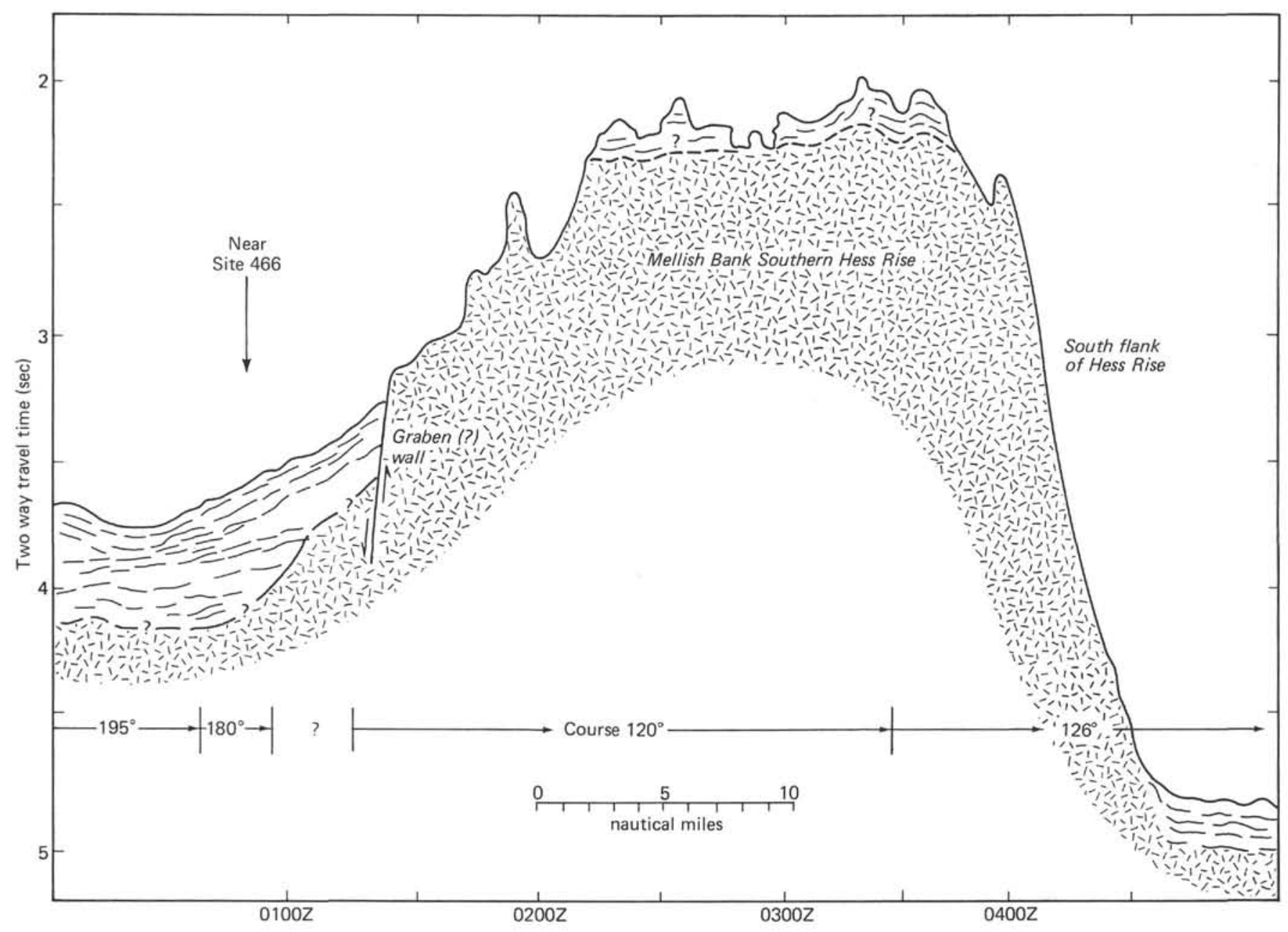

Figure 6. Line drawing of air-gun profile (5-sec. record) from traverse near Site 466 . Ship speed was about 9 knots. Vertical exaggeration is about $\times 20$. Site 466 is about 0.8 nautical miles away, but the profile is representative of the tectonic setting near Site 466 . 
T. L. VALLIER, K. E. WINDOM, K. E. SEIFERT, F. LEE-WONG

\section{REFERENCES}

Chase, T. E., Menard, H. W., and Mammerickx, J., 1970. Bathymetry of the North Pacific: Scripps Inst. Oceanogr. Inst. Mar. Res. Tech. Rept. Ser., 12.
Dalrymple, G. B., and Clague, D. A., 1976. Age of the HawaiianEmperor bend. Earth Planet. Sci. Lett., 31:313-329.

Fodor, R. V., Keil, K., and Bunch, T. E., 1975. Contributions to the mineral chemistry of Hawaiian rocks. IV. Pyroxenes in rocks from Haleakala and west Maui volcanoes, Maui, Hawaii. Contr. Mineral. Petrol., 50:173-195. 